\title{
PEMANFAATAN MEDIA PEMBELAJARAN DALAM PEMBELAJARAN BAHASA JEPANG DI KELAS X BAHASA SMA NEGERI 1 MELAYA
}

\author{
D. M. W. Wati ${ }^{1}$, I. W. Sadyana ${ }^{2}$, D. M. S. Mardani ${ }^{3}$ \\ ${ }^{123}$ Jurusan Pendidikan Bahasa Jepang, Universitas Pendidikan Ganesha, Singaraja \\ e-mail: made.widyana.wati@undiksha.ac.id, wayan.sadyana@undiksha.ac.id, desak.mardani@undiksha.ac.id
}

\begin{abstract}
Abstrak
Penelitian ini bertujuan untuk (1) mendeskripsikan pemanfaatan media pembelajaran dalam pembelajaran bahasa Jepang di kelas X Bahasa SMA Negeri 1 Melaya, (2) mendeskripsikan kendala yang dihadapi dalam pemanfaatan media pembelajaran bahasa Jepang di kelas $\mathrm{X}$ Bahasa SMA Negeri 1 Melaya serta upaya mengatasinya. Subjek penelitian ini adalah guru bahasa Jepang di SMA Negeri 1 Melaya. Pengumpulan data dilakukan dengan metode observasi, wawancara, dan dokumentasi. Data hasil penelitian akan dianalisis menggunakan metode deskriptif kualitatif. Hasil penelitian menunjukkan bahwa (1) pemanfaatan media pembelajaran bahasa Jepang di kelas $X$ Bahasa SMA Negeri 1 Melaya yang sudah dilaksanakan secara rutin yaitu media visual (powerpoint, laptop), media proyeksi diam ( $L C D$ projector), media visual sederhana (benda nyata yang ada di dalam kelas, papan tulis, kartu bergambar, kartu huruf, buku pelajaran berupa sakura 1 dan kira-kira nihongo), media audio (speaker). (2) Kendala yang dihadapi guru dalam pemanfaatan media yaitu berasal dari teknik pemilihan media dan karakteristik siswa. Solusi guru dalam mengatasi kendala pemanfaatan media pembelajaran yaitu menyesuaikan media pembelajaran dengan materi dan menyesuaikan media pembelajaran yang digunakan dengan kondisi peserta didik.
\end{abstract}

Kata kunci: media visual, media visual sederhana, media audio, media proyeksi diam, kendala

\begin{abstract}
要旨
本論は、その（1）ムラヤ第一国立高等学校一年生の日本語クラスに使用される学 習教材、（2）教師が直面する困難及び解決法を明らかにすること。対象は、ムラヤ 第一国立高等学校の日本語教師である。観察法及びインタビューで収集し、定性的 記述法により分析した。この結果、(1) ムラヤ第一国立高等学校一年生の日本語クラ スに使用される学習教材は、視聴覚メディア (パワーポイント、パソコン)、静止 画メディア(液晶プロジェクタ)、標本メディア（クラスの中にある実物）、印刷メ ディア（絵カード、文字カード、日本語教科書）、音声メディア（オーディオスピ 一カー）である。（2）教師が直面する困難は、適切な学習教材を選び方及び学生の特 徵である。解決法は授業のテーマ共に学生特長により適切な学習教材を選ぶことで ある。
\end{abstract}

キーワード : 視聴覚メディア、印刷メディア、音声メディア、静止画メディア、障害

\section{Pendahuluan}

Pendidikan sebagai bagian dari kebudayaan merupakan sarana penerus nilai dan gagasan setiap orang untuk mampu berperan serta dalam transformasi nilai dalam mencapai kemajuan bangsa dan negara. Untuk mewujudkan suatu pendidikan yang berkualitas dibutuhkan guru yang berkualitas. Guru yang berkualitas adalah guru yang mampu mewujudkan tujuan pendidikan nasional yakni yang memiliki kompetensi pedagogik, kompetensi kepribadian, kompetensi sosial, dan kompetensi professional.

Salah satu ciri guru professional adalah guru memiliki kreatifitas dan seni mendidik yang tinggi, sehingga mampu melakukan inovasi pembelajaran yang pada akhirnya siswa merasa nyaman dan menikmati proses pembelajaran yang terjadi (Uzer Usman, 2007). Kreatifitas dan jiwa seni yang tinggi dapat diarahkan pada hasil kreatifitas dan inovasi guru dalam menggunakan media pembelajaran.

Media pembelajaran merupakan bagian komponen pembelajaran dan menjadi bagian integral dari proses pembelajaran. Kata media merupakan bentuk jamak dari kata medium. Medium dapat didefinisikan sebagai perantara atau pengantar terjadinya komunikasi dari 
pengirim menuju penerima. Proses belajar mengajar merupakan proses komunikasi, penyampaian pesan dari pengantar ke penerima (Azwandi, 2007). Pesan yang disampaikan berupa isi atau ajaran yang dituangkan dalam simbol-simbol komunikasi baik secara verbal maupun non verbal. Usaha membuat pembelajaran lebih konkrit yaitu dengan menggunakan media pembelajaran. Media pembelajaran merupakan alat bantu mengajar yang dimana dapat mempermudah peserta didik menerima materi karena mendapat contoh konkrit dalam bentuk media. Manfaat lain media pembelajaran bagi peserta didik adalah proses pembelajaran lebih menarik dan menyenangkan. Sementara itu, manfaat media bagi guru yaitu dapat menggunakan waktu secara efisien dengan menggunakan media, salah satunya audio atau audio visual yang bisa menjangkau peserta didik dalam jangkauan yang luas dan jumlah yang banyak. Selain audio atau audio visual, ada berbagai jenis media lainnya yang dapat digunakan oleh guru.

Penggunaan media pembelajaran atau alat peraga dalam kegiatan pembelajaran akan mempengaruhi cara belajar siswa dan memberikan peluang pada siswa untuk belajar lebih baik, sehingga tujuan pembelajaran akan semakin mudah dicapai. Penggunaan media pembelajaran sudah banyak diterapkan di sekolah, salah satunya dalam pembelajaran bahasa Jepang.

Dalam dunia pendidikan, pembelajaran bahasa beragam jenisnya. Mata pelajaran bahasa inti di Indonesia adalah bahasa Indonesia. Selain itu, bahasa asing juga dimasukkan kedalam dunia pendidikan dan diuji dalam standar nasional salah satunya yaitu bahasa Jepang yang terdapat di SMA Negeri 1 Melaya. Perkembangan bahasa seseorang sangat besar pengaruhnya terhadap perkembangan kognitif seseorang. Akan tetapi, ada sebagian individu yang memiliki penguasaan kosakata yang terbatas, salah satunya adalah anak berkesulitan belajar bahasa, khususnya pada mata pelajaran bahasa Jepang karena pelajaran ini merupakan pelajaran bahasa untuk pemula yang di tingkat sekolah sebelumnya belum diberikan pelajaran bahasa Jepang. Kesulitan dalam belajar bahasa Jepang dikarenakan siswa kesulitan dalam menghafal huruf Jepang yaitu Kanji, Hiragana, dan Katakana yang berbeda dengan huruf abjad dan masing-masing huruf tersebut mempunyai karakteristik yang harus diketahui dan dipahami oleh pembelajar bahasa Jepang.

Menurut Renariah (2002) menyatakan bahwa bahasa Jepang memiliki karakteristik yang wajib diketahui dan dipahami oleh pembelajar bahasa Jepang, yaitu hatsuon, moji, goi, bunpou, dan hyogen yang bilamana secara berurutan dalam bahasa Indonesia adalah ucapan, huruf, kosakata, tata bahasa dan ekspresi. Agar bisa berbahasa Jepang dengan baik, dalam hal berbicara, menulis, yang pertama harus dipelajari dan dikuasai adalah menghafal huruf-huruf bahasa Jepang yang ada. Untuk itu, kreatifitas guru dalam pemanfaatan media pembelajaran dalam proses belajar di kelas sangat diperlukan agar peserta didik tidak kesulitan menghafal huruf Jepang.

Berdasarkan wawancara awal dengan guru pengampu mata pelajaran bahasa Jepang di SMA Negeri 1 Melaya, diperoleh informasi bahwa SMA Negeri 1 Melaya yang beralamatkan di jalan Denpasar-Gilimanuk, desa Melaya, kabupaten Jembrana merupakan sekolah menengah atas (SMA) yang sudah terakreditasi A, memberlakukan kurikulum 2013, dan menerapkan pembelajaran berbasis $4 \mathrm{C}$ serta menerapkan sistem full day school. Selain itu, SMA Negeri 1 Melaya memiliki daya saing yang cukup tinggi dalam kualitas pendidikan, memiliki tiga jurusan yaitu jurusan Bahasa, jurusan IPA dan jurusan IPS. Semua jurusan sudah menggunakan media dalam proses pembelajaran. Khusus untuk jurusan bahasa, penggunaan media pembelajaran yang diterapkan tergantung dengan materi pembelajaran yang diajarkan, media yang digunakan guru ketika mengajar sangat bervariasi, seperti speaker, powerpoint, kartu bergambar dan benda nyata yang ada di lingkungan kelas, namun media yang paling sering digunakan adalah powerpoint karena dianggap lebih praktis dan efisien terhadap waktu. Media pembelajaran tidak selalu digunakan, karena harus menyesuaikan dengan materi yang diajarkan dan kriteria materi pembelajaran disusun berdasarkan silabus.

Dilihat dari penjelasan yang telah dipaparkan tersebut, diperlukan suatu penelitian yang khusus dalam menganalisis penggunaan media dalam pembelajaran bahasa Jepang yaitu mengenai pemanfaatan media pembelajaran bahasa Jepang kelas $X$ bahasa SMA Negeri 1 Melaya. Adapun alasan penelitian ini hanya berfokus pada kelas $X$ bahasa saja karena kelas $X$ bahasa merupakan pembelajar pemula untuk mempelajari bahasa asing salah satunya 
bahasa Jepang. Materi pembelajarannya tematik dan masih merupakan materi dasar bahasa Jepang. Oleh karena itu, penggunaan media pembelajaran harus menyesuaikan dengan materi yang telah ditentukan oleh kurikulum yang berlaku.

Apabila dalam proses belajar mengajar guru melakukan pemanfaatan media, maka peserta didik akan memiliki pemahaman yang bagus tentang materi yang didapatkan sehingga besar kemungkinan dengan memperhatikan media pengajaran, tujuan pembelajaran akan tercapai dengan efektif dan efisien.

Penelitian mengenai media pembelajaran sebelumnya sudah pernah dilakukan oleh Mardani (2012) dalam penelitiannya membahas mengenai pemanfaatan media visual untuk meningkatkan kemampuan menulis hiragana dan katakana. Penelitian tersebut memfokuskan pada huruf hiragana dan katakana, karena huruf tersebut merupakan huruf yang pertama kali diajarkan sebelum pembelajar mulai mengenal huruf kanji. Hasil penelitiannya menunjukkan bahwa penerapan media visual dan metode tugas dapat meningkatkan kemampuan menulis indah pada mahasiswa Jurusan Pendidikan Bahasa Jepang Undiksha.

Penelitian lainnya yang sejenis oleh Keniten (2017) dalam penelitiannya membahas mengenai Pengembangan Media Pembelajaran Bahasa Jepang Berbasis Adobe Flash Professional CS6 untuk Meningkatkan Kemampuan Mengingat Kosakata Siswa Kelas XI Di SMKN 4 Negara. Berdasarkan angket yang diberikan kepada siswa menunjukkan bahwa, siswa menginginkan media pembelajaran modern yang tampilannya jelas, berwarna, dan memiliki gambar nyata. Berdasarkan angket uji ahli, media pembelajaran kosakata bahasa Jepang berbasis adobe flash professional cs6 yang dibuat sudah sesuai dengan silabus bahasa Jepang di SMKN 4 Negara. Berdasarkan angket uji terbatas, media pembelajaran kosakata bahasa Jepang berbasis adobe flash professional cs 6 yang dibuat sudah sangat sesuai dengan silabus bahasa Jepang di SMKN 4 Negara.

Kedua penelitian yang telah disebutkan diatas dapat disimpulkan bahwa media pembelajaran yang digunakan sangat berperan penting dalam proses pembelajaran. Dengan kata lain, kehadiran media pembelajaran sangat membantu dalam mencapai tujuan pembelajaran. Begitu pentingnya media pembelajaran dalam mencapai keberhasilan proses pembelajaran. Maka dalam penelitian yang dibahas ini, ingin diketahui bagaimana pemanfaatan media pembelajaran yang dilakukan di kelas $X$ bahasa SMA Negeri 1 Melaya, dan kendala-kendala yang dihadapi oleh guru dalam pemanfaatan media pembelajaran bahasa Jepang serta cara mengatasi kendala tersebut, sehingga nantinya akan dapat lebih melengkapi penelitian sebelumnya.

\section{Metode}

Penelitian ini membahas tentang Pemanfaatan media pembelajaran dalam bembelajaran bahasa jepang di kelas X Bahasa SMA Negeri 1 Melaya. Pendekatan yang digunakan dalam penelitian ini adalah kualitatif. Subjek dari penelitian ini adalah guru bahasa Jepang di SMA Negeri 1 Melaya. Metode pengumpulan data yang digunakan terdiri dari metode observasi, wawancara, dan dokumentasi. Selanjutnya data hasil penelitian yang diperoleh akan dianalisis menggunakan teknik analisis data yaitu: Tabulasi Data, Reduksi Data, Deskripsi Data, Klasifikasi Data, Penarikan Kesimpulan dan Pengecekan Keabsahan Data.

\section{Hasil dan Pembahasan}

Proses pemanfaatan media pembelajaran merupakan tahap implementasi program yang telah disusun. Dalam tahap ini kemampuan yang dituntut adalah ketelitian, kreatifitas guru dalam melaksanakan kegiatan pemanfaatan media pembelajaran sesuai rencana yang telah disusun. Dalam pemanfaatan media pembelajaran, harus terencana secara sistematis yang memperhatikan tujuan, prosedur, target/sasaran serta jenis media yang ada. Dari pemaparan tersebut menunjukkan bahwa hal yang dilakukan guru dalam pemanfaatan media pembelajaran benar-benar mendukung teori Musqifon (2012) yang mengatakan dalam memilih media harus berdasarkan kesesuaian media dan keterampilan guru dalam memilih serta menggunakan media pembelajaran. 
Pelaksanaan media pembelajaran bahasa Jepang di kelas $X$ bahasa SMA Negeri 1 Melaya sudah berjalan sesuai prosedur. Melalui pemanfaatan media pembelajaran bahasa Jepang secara garis besar tujuan pembelajaran dapat tercapai. Dengan pelaksanaan pemanfaatan media pembelajaran dapat bermanfaat untuk mempermudah guru dan siswa lebih aktif dalam pembelajaran, membuat suasana KBM lebih hidup dan menyenangkan, meningkatkan kemampuan mengajar dan meningkatkankan pemahaman siswa. Pemanfaatan media pembelajaran sudah sesuai dengan tujuan pembelajaran, dalam pemanfaatan jenis media dengan mempertimbangkan waktu, materi pembelajaran dan kemampuan siswa. Kadang-kadang dalam pelaksanaan guru menggunakan lebih dari satu jenis media jika dibutuhkan.

Dari hasil wawancara dan observasi mengenai pemanfaatan media pembelajaran bahasa Jepang di kelas $X$ Bahasa SMA Negeri 1 Melaya dapat diperoleh gambaran bahwa pemanfaatan media pembelajaran di sekolah ini dilaksanakan secara rutin yakni dilihat pada observasi pertama sampai dengan observasi ke enam, media yang digunakan guru adalah media visual (powerpoint, laptop), media visual sederhana (benda nyata yang ada di dalam kelas, papan tulis, kartu bergambar, kartu huruf, buku pelajaran berupa sakura 1 dan kirakira nihongo), media audio (speaker), media proyeksi diam (LCD Projector).

Laptop digunakan guru untuk mempersiapkan serta menyimpan materi pembelajaran yang kemudian ditampilkan di depan kelas, dengan menggunakan $L C D$ Projector. Penggunaan $L C D$ Projector membuat siswa di dalam kelas dapat melihat dan mengamati materi pembelajaran. Media tersebut digunakan oleh guru untuk menampilkan dan menampilkan contoh kosakata, contoh pola kalimat bahasa Jepang yang berkaitan dengan materi pembelajaran. Hal tersebut sesuai dengan teori yang dikemukakan oleh Kimura Muneo dan kawan-kawan (1992) telah menjelaskan berbagai macam media pengajaran di dalam bukunya yang berjudul Nihongo Kyoujuhou. Menurutnya ada beberapa media yang digunakan dalam pembelajaran bahasa Jepang yakni media visual sederhana, media proyeksi diam, media audio, media film dan media komputer.

Pemanfaatan media pembelajaran bahasa Jepang di kelas X Bahasa SMA Negeri 1 Melaya ditentukan berdasarkan materi yang diajarkan. Guru tidak selalu menggunakan media pembelajaran di kelas karena harus mengkondisikan dengan materi dan situasi kelas, untuk kelas $X$ diusahakan menggunakan media karena materi pembelajaran di kelas $X$ adalah materi pembelajaran dasar. Dengan adanya media pembelajaran dapat memudahkan siswa dalam menerima dan memahami materi pembelajaran melalui media dibandingkan harus berimajinasi tanpa menggunakan media.

Dalam memilih media harus memenuhi aspek dan unsur yang bisa membuat proses pembelajaran semakin efektif. Oleh karena itu, dalam penggunaannya tentu media harus memiliki beberapa kriteria yang kemudian harus dipenuhi agar sesuai dengan proses pembelajaran. Hal tersebut mendukung teori tentang kriteria pemilihan media oleh Musqifon (2012) yang menyatakan bahwa memilih media harus berdasarkan kesesuaian media serta keterampilan guru dalam memilih dan menggunakan media dalam pembelajaran. Berikut ini diuraikan pemanfaatan media dalam pembelajaran bahasa Jepang yang meliputi :

a. Kesesuaian media pembelajaran dengan tujuan pembelajaran

Media yang digunakan pada observasi pertama pada pembelajaran bahasa Jepang yaitu buku sakura 1, buku kira-kira nihongo, Laptop, powerpoint, LCD, speaker. Dengan tujuan pembelajaran siswa dapat menyebutkan jenis salam dalam bahasa Jepang (aisatsu), kosakata mengenai salam dalam bahasa Jepang dan contoh kalimat. Media yang digunakan sudah sesuai dengan kompetensi dasar yang ditetapkan secara umum. Media powerpoint, $L C D$, speaker sudah dapat melibatkan siswa dalam pemanfaatannya dan mendukung salah satu ranah yaitu ranah kognitif (siswa dapat menyebutkan).

Media yang digunakan pada observasi kedua yaitu Media powerpoint, $L C D$, speaker dan kartu bergambar. Dengan tujuan pembelajaran yaitu siswa dapat menyebutkan jenis salam dalam bahasa Jepang, mampu menyebutkan kosakata serta contoh kalimat. Media yang digunakan sudah sesuai dengan tujuan pembelajaran sehingga dapat meningkatkan respon siswa dalam salah satu ranah yaitu ranah kognitif.

Media yang digunakan pada observasi ketiga yaitu buku sakura 1, kira-kira nihongo dan papan tulis. Dengan tujuan pembelajaran yaitu siswa dapat menyebutkan cara memperkenalkan diri dalam bahasa Jepang serta membuat contoh pola kalimat. Media yang 


\section{digunakan sudah sesuai dengan tujuan pembelajaran.}

Media yang digunakan pada observasi keempat yaitu native speaker, papan tulis serta benda nyata di dalam kelas berupa kalender. Dengan tujuan pembelajaran yaitu siswa mampu menyebutkan nama tanggal dan bulan dalam bahasa Jepang sesuai pelafalan yang tepat dan sesuai. Tujuan pembelajaran yang digunakan sudah sesuai tujuan pembelajaran.

Media yang digunakan pada observasi kelima yaitu papan tulis serta benda nyata di dalam kelas berupa kalender. Dengan tujuan pembelajaran yaitu siswa mampu membuat contoh pola kalimat dengan tema hari, tanggal dan bulan dalam bahasa Jepang. Media yang digunakan sudah sesuai dengan tujuan pembelajaran yaitu melibatkan siswa dalam pemanfaatannya, seperti penggunaan kalender untuk melatih siswa dalam membuat kalimat dalam bahasa Jepang sesuai tanggal yang ditunjukkan oleh guru.

Media yang digunakan pada observasi keenam yaitu laptop, powerpoint, $L C D$. Dengan tujuan pembelajaran yaitu siswa mampu menyebutkan jenis-jenis nama mata pelajaran dalam bahasa Jepang dan cara menyebutkan jadwal pelajaran dalam bahasa Jepang. Media yang digunakan sudah sesuai dengan tujuan pembelajaran. Hal ini didukung dari data observasi yaitu guru menampilkan gambar berupa kosakata pada powerpoint, kemudian menyuruh siswa menebak maksud dari gambar tersebut.

\section{b. Kesesuaian media pembelajaran dengan materi}

Media powerpoint, $L C D$, Speaker yang digunakan pada observasi pertama (materi aisatsu), observasi kedua (materi aisatsu) dan observasi keenam (materi jenis-jenis nama pelajaran) sudah mendukung materi pembelajaran yang disampaikan karena bersifat fakta dan konsep yang memudahkan siswa dalam memahami materi dengan contoh nyata berupa media tanpa harus berimajinasi. Media kartu bergambar yang digunakan pada observasi kedua juga sesuai dengan materi yang disampaikan. Hal tersebut didukung dari data hasil observasi yakni dilihat saat guru menggunakan media kartu bergambar dalam menyampaikan materi aisatsu. Guru memperlihatkan kartu bergambar kepada siswa dan menginstruksikan siswa untuk menebak kosakata yang ditunjukkan melalui kartu bergambar. Media kartu huruf yang digunakan oleh guru pada observasi ketiga juga sesuai dengan materi yang diajarkan, yakni media tersebut digunakan untuk mengecek pemahaman siswa terhadap huruf hiragana. Dalam pembelajaran, guru memperlihatkan kartu huruf secara acak, kemudian menyuruh siswa menyebutkan huruf yang ditunjukkan.

Selain itu, pemanfaatan media visual sederhana berupa benda nyata seperti kalender yang ada di kelas, seorang native speaker (penutur asli bahasa Jepang), papan tulis, buku sakura 1 dan kira-kira nihongo pada observasi keempat dan observasi kelima yang pada saat itu menyampaikan materi mengenai hari, tanggal dan bulan dalam bahasa Jepang sudah sesuai dengan materi pembelajaran. Hal tersebut dilihat saat observasi yaitu ketika guru menuliskan contoh pola kalimat pada papan tulis, yang kemudian mengajak siswa untuk membaca dan memahami maksud dari pola kalimat tersebut. Setelah itu, guru melatih pemahaman siswa terhadap materi yang dijelaskan menggunakan kalender untuk menyuruh siswa membuat contoh pola kalimat sesuai dengan hari, tanggal, dan bulan yang ditunjukkan. Guru juga mengajak native speaker untuk mengajarkan siswa latihan mengucapkan hari, tanggal, dan bulan dalam bahasa Jepang sesuai pelafalan yang baik dan benar.

\section{c. Kesesuaian media pembelajaran dengan kondisi peserta didik}

Media yang digunakan sudah menimbulkan interaksi langsung antara siswa dengan media yang digunakan. Media yang digunakan juga sudah memperhatikan kondisi peserta didik. Hal ini dilihat dari observasi pertama sampai dengan observasi keenam, media yang digunakan adalah media visual (powerpoint), visual sederhana (papan tulis, buku pelajaran dan benda nyata), media audio (speaker) dan media proyeksi diam (LCD Projector). Siswa antusias memperhatikan pembelajaran dengan media tersebut, seperti penggunaan media visual sederhana yaitu benda nyata berupa kalender dalam membahas materi hari, tanggal dan bulan pada observasi keempat dan observasi kelima siswa tertarik untuk latihan pola kalimat bahasa Jepang sesuai dengan materi yang diajarkan. Berdasarkan media tersebut, siswa dapat melihat secara langsung nama hari, tanggal dan bulan dan menyebutkannya dalam bahasa Jepang. Sehingga media ini sudah sesuai dengan tahap berpikir anak yaitu operasional konkrit, media yang digunakan juga membangkitkan minat dan motivasi siswa 
untuk belajar.

Berdasarkan beberapa uraian di atas mengenai pemanfaatan media pembelajaran bahasa Jepang, telah mendukung teori tentang kriteria pemilihan media dari Hartanto Kasmadi dalam Rohani (1997) yang menyarankan ketika hendak menggunakan atau memilih media pembelajaran perlu mempertimbangkan : produksi, peserta didik, isi (materi pembelajaran), dan pertimbangan guru. Pemilihan media pembelajaran yang akan digunakan dalam proses belajar mengajar yang memperhatikan kriteria-kriteria tersebut, akan menghasilkan atau menemukan media pembelajaran yang berkualitas dan sesuai atau tepat digunakan untuk masing-masing materi pembelajaran. Media pembelajaran yang dipilih juga membantu guru menyampaikan materi kepada siswa. Siswa juga lebih mudah menerima serta memahami pembelajaran dengan bantuan media pembelajaran yang sudah dipilih berdasarkan kriteria yang ditentukan.

Adapun tiga langkah yang dilakukan guru saat proses pemanfaatan media pembelajaran yakni : (1) langkah persiapan. Pada langkah ini guru memastikan media yang digunakan untuk mengajar dapat berfungsi dengan baik dan guru memastikan di ruang kelas sudah tersedia power listrik untuk menampilkan media pembelajaran. (2) langkah pelaksanaan. Pada langkah ini guru menjelaskan kepada peserta didik tentang jenis materi yang dibahas dan tujuan pembelajaran yang ingin dicapai serta guru mengusahakan suasana di kelas agar tetap tenang dan kondusif selama pemanfaatan media. (3) langkah tindak lanjut. Pada langkah ini guru meminta siswa menanyakan berbagai hal yang dianggap kurang dipahami (yang berhubungan dengan materi pelajaran yang dipelajari melalui pemanfaatan media) dan guru memberikan tes untuk mengukur tingkat keberhasilan siswa dalam mengikuti pembelajaran melalui pemanfaatan media.

Selain itu, hal-hal yang mendasari dalam pemanfaatan dan pemilihan media diantaranya seperti memilih media yang disesuaikan dengan materi ajar. Saat pembelajaran kosakata, guru menggunakan jenis media visual sederhana yakni berupa media kartu gambar yang cocok digunakan karena media tersebut mudah dibuat dan mudah diaplikasikan kepada siswa. Caranya dengan menunjukkan kartu gambar tersebut yang berupa contoh kosakata, kemudian guru menginstruksikan kepada siswa untuk menebak maksud dari gambar yang ditunjukkan. Hal ini dapat melatih kemampuan daya pikir siswa dengan mengamati suatu objek secara langsung dalam menemukan dan mengetahui informasi baru. Pemanfaatan jenis media visual seperti media powerpoint juga dapat menampilkan contoh kosakata dengan tampilan gambar menarik untuk memotivasi siswa agar tetap fokus dalam mengikuti pembelajaran, dapat menyajikan teks, gambar, foto atau animasi dan video sehingga lebih menarik. Tempo dan penyajiannya bisa disesuaikan serta dapat digunakan secara berulangulang. Selanjutnya media audio (speaker) yang digunakan guru dalam menyampaikan contoh kosakata dan pola kalimat melalui audio yang ditampilkan sehingga siswa dapat mendengar serta dapat menyimak audio yang ditampilkan oleh guru dan berlatih melakukan pengucapan kosakata dan pola kalimat bahasa Jepang yang baik dan benar.

Berdasarkan uraian yang telah dipaparkan di atas, mendukung teori dari Asyhar (2012) tentang prosedur pemilihan media, yang menyatakan bahwa pembelajaran yang efektif memerlukan perencanaan yang baik apabila suatu media yang digunakan bervariasi. Maka dalam penggunaannya harus berdasarkan prosedur yang sistematik, yang didasari oleh beberapa faktor yaitu menelaah tujuan pembelajaran. Tujuan pembelajaran menjadi faktor pertimbangan dalam pemilihan media karena jenis kompetensi yang diharapkan tercapai sangat terkait dengan jenis media yang digunakan. Selain itu, faktor dari karakteristik bahan ajar juga menentukan pemilihan media dalam pembelajaran sesuai dengan karakteristik siswa yang berbeda-beda, yang diperlukan kreatifitas guru dan inovasi dalam menentukan pilihan jenis media apa yang digunakan. Selanjutnya, dari faktor "menetapkan pemilihan media" yang terkait dengan karakteristik siswa, materi ajar dan tujuan yang ingin dicapai dalam pembelajaran, dengan mempertimbangkan kriteria lain seperti kebijakan, fasilitas tersedia dan kemampuan produksi.

Pembelajaran bahasa Jepang di SMA Negeri 1 Melaya menggunakan alur pembelajaran yang dikategorikan menjadi 3 tahapan yang terdiri atas tahapan dounyuu, kihon renshuu dan oyou renshuu. Tahap dounyuu terletak pada awal pembelajaran, yaitu pada proses pemahaman makna yang berupa kosakata ataupun pola kalimat yang diberikan oleh guru. Guru mengawali pembelajaran dengan menampilkan contoh kosakata dan contoh pola 
kalimat berupa tampilan gambar menggunakan media powerpoint. Guru menginstruksikan kepada siswa untuk menebak maksud dari gambar yang ditampilkan.

Tahap kihon renshuu adalah tahap latihan dasar. Pada tahap ini terdapat pada inti pembelajaran. Kegiatan yang dilakukan siswa pada tahap ini adalah mengingat materi. Setelah guru memberikan penjelasan dan pemahaman pada siswa terhadap materi yang diajarkan, guru meminta siswa untuk latihan membuat contoh kalimat yang telah dijelaskan pada powerpoint. Guru menampilkan contoh kosakata dan pola kalimat pada slide powerpoint yang kemudian siswa diminta untuk mengamati dan mencoba membuat contoh pola kalimat sesuai dengan yang ditampilkan pada powerpoint. Siswa diharapkan mampu mengembangkan ide serta gagasannya dalam membuat suatu kalimat.

Pada tahap oyou renshuu atau disebut dengan tahap latihan akhir. Pada tahap ini siswa mampu menggunakan apa yang sebelumnya sudah dipelajari. Guru menggunakan media kartu bergambar dengan menunjukkan kartu bergambar kepada siswa yang kemudian menyuruh siswa membuat contoh percakapan bersama teman sebangku. Setelah itu, guru menunjuk siswa yang sudah bisa, kemudian menyuruh untuk menyampaikan contoh percakapan. Adanya kegiatan ini akan membiasakan siswa untuk mengutarakan ide dan gagasannya berdasarkan contoh nyata berupa kartu bergambar yang ditunjukkan oleh guru. Selain itu, penggunaan media speaker yang dimanfaatkan oleh guru untuk menampilkan audio berupa cara pengucapan kosakata dan pola kalimat dalam bahasa Jepang yang baik dan benar. Selama pemutaran audio siswa dituntut untuk mendengar dan menyimak, kemudian mencatat di buku tulis audio yang telah didengar. Audio diputar sebanyak 2 kali. Setelah itu, guru menginstruksikan siswa untuk menyampaikan audio berupa contoh kosakata dan contoh pola kalimat secara bersama-sama.

Adapun kendala-kendala yang dialami guru selama proses pemanfaatan media pembelajaran serta cara mengatasi kendala tersebut yaitu kendala yang sering dialami guru yaitu dari "aspek persiapan pemilihan media", mulanya media yang dipilih sudah tepat dengan materi, terkadang persepsi gambar yang dibuat oleh guru dengan respon gambar yang dilihat oleh siswa berbeda-beda. Selain itu, ketika sudah mempersipkan LCD Projector dan Powerpoint tetapi tiba-tiba listrik di sekolah mati. Cara mengatasinya yaitu mengajar seadanya atau menggunakan media papan tulis dan buku pelajaran. Selanjutnya kendala yang dilihat dari "segi pemilihan medianya" yaitu ketika memakai full colour pada tampilan powerpoint, siswa menjadi kurang fokus terhadap materi yang disampaikan, siswa mengalihkan perhatiannya terhadap banyaknya variasi warna yang terlihat pada layar powerpoint. Cara guru mengatasinya yaitu berusaha mengalihkan perhatian siswa untuk kembali fokus pada materi yang dijelaskan dan untuk pembelajaran selanjutnya media diganti dengan tampilan powerpoint yang baru. Kendala yang terjadi dari segi karakteristik siswa yaitu siswa memiliki karakteristik yang berbeda-beda, guru sering menjumpai beberapa siswa yang sulit diatur. Sulit diatur dalam arti ketika guru sudah mencoba menegur dan memberi tahu kepada siswa tersebut masih berperilaku yang tidak sewajarnya. Cara mengatasinya yaitu guru harus memperhatikan siswa, jika ada siswa yang berperilaku tidak sewajarnya dan tidak memperhatikan guru, siswa tersebut diberikan pertanyaan mengenai materi yang telah diajarkan dan ditunjuk secara spontan.

Kendala yang terjadi dalam proses pemanfaatan media pembelajaran bahasa Jepang dilihat berdasarkan "penerimaan siswa" yaitu dilihat dari karakteristik siswa yang berbeda, dari banyaknya siswa dalam satu kelas tidak ada yang memiliki kepribadian yang sama, sifat dan sikapnya berbeda-beda. Ada siswa yang benar-benar memperhatikan guru ketika mengajar dan ada pula siswa yang bersikap diluar batas wajar, seperti etika berbicara yang tidak sopan yang sering kali meniru dan menanggapi pembicaraan guru dalam menyampaikan materi yang dijelaskan, sebelum guru memberikan perintah untuk meniru ataupun latihan pengucapan contohnya seperti pembelajaran kosakata dan pola kalimat, masih saja ada siswa yang meniru cara guru mengucapkan atau hatsuon dari guru. Jadi untuk mengatasi hal tersebut, guru biasanya memberikan pertanyaan dan menyuruh siswa tersebut untuk menjawab, jika tidak bisa menjawab, guru menyuruh siswa tersebut untuk maju ke depan kelas dan berdiri hingga jam pelajaran selesai. Tindakan yang dilakukan guru tersebut adalah memberi efek jera kepada siswa agar lebih bersikap sopan terhadap guru.

Ketika dalam proses pemanfaatan media pembelajaran, guru menemukan beberapa kendala yang didasari dari faktor persiapan pemilihan media, segi pemilihan media, dan 
karakteristik siswa. Kendala yang dihadapi guru tersebut sesuai dengan teori yang diungkapkan oleh Ashyar (2012) bahwa pembelajaran yang efektif memerlukan perencanaan yang baik, apabila suatu media yang digunakan bervariasi maka dalam pemanfaatannya harus berdasarkan prosedur yang sistematik. Kendala yang sering dialami guru yaitu dari "aspek persiapan pemilihan media", mulanya media yang dipilih sudah tepat dengan materi, namun terkadang persepsi gambar yang dibuat oleh guru dengan respon gambar yang dilihat oleh siswa berbeda-beda. Selain itu, ketika sudah mempersipkan LCD projector dan powerpoint tetapi tiba-tiba listrik di sekolah mati. Cara mengatasinya yaitu mengajar seadanya atau secara manual dengan menggunakan media papan tulis dan buku pelajaran.

Selanjutnya kendala yang dilihat dari "segi pemilihan medianya" yaitu ketika memakai full colour pada tampilan powerpoint, tetapi siswa kurang fokus terhadap materi yang disampaikan, siswa mengalihkan perhatiannya terhadap banyaknya warna yang terlihat pada powerpoint. Cara guru mengatasinya yaitu berusaha mengalihkan perhatian siswa untuk kembali fokus pada materi yang dijelaskan dan untuk pembelajaran selanjutnya media tersebut tidak dipakai lagi dan diganti dengan tampilan powerpoint yang baru. Kendala yang terjadi dari segi karakteristik siswa yaitu siswa memiliki karakteristik yang berbeda-beda, guru sering menjumpai beberapa siswa yang sulit diatur. Sulit diatur dalam arti ketika guru sudah mencoba menegur dan memberi tahu kepada siswa tersebut masih berperilaku yang tidak sewajarnya. Jika pada tahap yang sulit dikendalikan guru menyerahkan siswa kepada wakabid kesiswaan untuk ditindak lanjuti. Sebelum itu, biasanya guru memberikan ancaman tegas seperti " kalau masih ribut seperti ini lebih baik jika tidak suka pelajaran saya keluar saja dari ruang kelas ini". Dengan begitu, siswa biasanya akan kembali patuh pada guru, tindakan yang dilakukan oleh guru sejalan dengan teori Munadi (2008) bahwa karakteristik yang bersifat khusus seperti sikap awal yang dimiliki peserta didik akan membawa pengaruh dalam menjalani aktivitas. Cara mengatasinya yaitu guru harus memperhatikan siswa, jika ada siswa yang berperilaku tidak sewajarnya dan tidak memperhatikan guru, siswa tersebut diberikan pertanyaan mengenai materi yang telah diajarkan dan ditunjuk secara spontan.

Kendala yang terjadi dalam proses pemanfaatan media pembelajaran bahasa Jepang dilihat berdasarkan "penerimaan siswa" yaitu mengingat bahwa karakteristik siswa yang bermacam-macam, pasti ada saja hal-hal yang tidak diinginkan yang terjadi dalam penyampaian materi di kelas, dari banyaknya siswa dalam satu kelas tidak semua memiliki kepribadian yang sama, sifat dan sikapnya berbeda-beda. Ada siswa yang benar-benar memperhatikan guru ketika mengajar dan ada pula siswa yang bersikap diluar batas wajar, seperti etika berbicara yang tidak sopan yang sering kali meniru dan menanggapi pembicaraan guru dalam menyampaikan materi yang dijelaskan, sebelum guru memberikan perintah untuk meniru ataupun latihan pengucapan contohnya seperti pembelajaran kosakata dan pola kalimat, masih saja ada siswa yang meniru cara guru mengucapkan atau hatsuon dari guru. Jadi untuk mengatasi hal tersebut, guru biasanya memberikan pertanyaan dan menyuruh siswa tersebut untuk menjawab, jika masih saja tidak bisa menjawab, siswa tersebut diperintahkan untuk maju ke depan kelas dan berdiri hingga jam pelajaran selesai. Tindakan yang dilakukan guru tersebut adalah memberi efek jera kepada siswa agar lebih bersikap sopan terhadap guru.

\section{Simpulan dan Saran}

Berdasarkan pada hasil penelitian dan pembahasan, maka simpulan dari penelitian ini adalah sebagai berikut.

Pemanfaatan media dalam pembelajaran bahasa Jepang di kelas $X$ bahasa SMA Negeri 1 Melaya yaitu dapat diperoleh gambaran bahwa pemanfaatan media pembelajaran di sekolah ini sudah dilaksanakan secara rutin yakni dilihat pada observasi pertama sampai dengan observasi ke enam, jenis media yang digunakan guru adalah media visual (powerpoint, laptop), media visual sederhana (benda nyata yang ada di dalam kelas, papan tulis, kartu bergambar, kartu huruf, buku pelajaran berupa sakura 1 dan kira-kira nihongo), media audio (speaker), media proyeksi diam (LCD Projector).

Kendala yang dialami guru selama proses pemanfaatan media pembelajaran serta cara mengatasi kendala tersebut yaitu kendala yang sering dialami guru yaitu dari "aspek persiapan pemilihan media", mulanya media yang dipilih sudah tepat dengan materi, terkadang persepsi gambar pada tampilan powerpoint yang dibuat oleh guru dengan respon 
yang dilihat oleh siswa berbeda-beda. Solusinya mengajar menggunakan media seadanya seperti papan tulis dan buku pelajaran. Kendala dari "segi pemilihan medianya" yaitu ketika memakai full colour pada tampilan powerpoint, siswa menjadi kurang fokus terhadap materi yang disampaikan karena lebih memperhatikan tampilan warna pada layar powerpoint. Solusinya dengan melakukan perubahan terhadap tampilan powerpoint pada pembelajaran selanjutnya. Kendala yang terjadi dari segi "karakteristik siswa" yaitu ada siswa beberapa siswa yang sulit diatur. Solusinya yaitu jika ada siswa yang berperilaku tidak sewajarnya, siswa tersebut ditunjuk secara spontan untuk menjawab pertanyaan dari guru. Kendala yang terjadi dilihat berdasarkan "penerimaan siswa" yaitu sikap siswa ada yang benar-benar memperhatikan guru ketika mengajar serta ada pula siswa yang bersikap diluar batas wajar. Solusinya, guru memberikan pertanyaan mengenai materi dan menyuruh siswa tersebut untuk menjawab, jika tidak bisa menjawab, diperintahkan untuk maju ke depan kelas dan berdiri hingga jam pelajaran selesai. Hal tersebut dilakukan oleh guru untuk memberi efek jera kepada siswa.

Berdasarkan temuan-temuan yang diperoleh dalam penelitian ini, saran yang disampaikan adalah sebagai berikut.

Bagi guru mata pelajaran bahasa Jepang, pemilihan media pembelajaran perlu perencanaan yang matang, karena harus menimbang banyak hal, seperti salah satunya harus sesuai dengan materi yang akan diajarkan, dan juga penimbangan bahwa setiap kelas mempunyai gaya belajar yang berbeda, tidak menutup kemungkinan bahwa media yang sama kurang bisa digunakan pada kelas yang sama.

Bagi peneliti khususnya di bidang bahasa Jepang, dapat menggunakan penelitian ini sebagai bahan rujukan untuk melakukan penelitian sejenis mengenai pemanfaatan media pembelajaran de ngan materi bahasa Jepang. Misalnya pemanfaatan media pembelajaran untuk meningkatkan efektivitas pembelajaran bahasa Jepang

\section{Daftar Pustaka}

Ahmad Rohani. 1997. Media Insruksional Edukatif. Jakarta: PT Rhineka Cipta.

Asyhar, Rayandra. 2012. Kreatif Mengembangkan Media Pembelajaran. Jakarta: Referensi Jakarta.

Azwandi, Yosfan. 2007. Media Pembelajaran Anak Berkebutuhan Khusus. Jakarta: Departemen Pendidikan Nasional Direktorat Jenderal Pendidikan Tinggi Direktorat Ketenagaan.

Keniten, I. G. N. A.2017. "Pengembangan Media Pembelajaran Bahasa Jepang Berbasis Adobe Flash Professional CS6 untuk Meningkatkan Kemampuan Mengingat Kosakata Siswa Kelas XI di SMK N 4 Negara". Singaraja: Jurnal Pendidikan Bahasa Jepang, Vol.3, No.1. Tersedia pada : https://ejournal.undiksha.ac.id/index.php/JJPBJ/article/view/11193/pdf (diakses tanggal 12 Januari 2020)

Mardani, D. M. S. 2012. "Pemanfaatan Media Visual untuk Meningkatkan Kemampuan Menulis Huruf Hiragana dan Katakana". Singaraja: Jurnal Pendidikan dan Pengajaran, Vol.45, No.3. Tersedia pada : http://ejournal.undiksha.ac.id/index.php/JPP/article/view/1836/1606 (diakses tanggal 15 Juni 2019).

\footnotetext{
Munadi, Yudi. 2008. Media Pembelajaran Sebuah Pendekatan Baru.Ciputat: Gaung Persada (GP) Press.
} 
Muneo, Kimura, dkk. (1992). Nihongo Kyoujuhou. Tokyo: Oofusha.

Musqifon. 2012. Pengembangan Media dan Sumber Media Pembelajaran. Jakrta: PT. Prestasi Pustakaraya.

Renariah. 2002. "Bahasa Jepang dan Karakteristiknya" . Jurnal Sastra Jepang Fakultas Sastra Universitas Kristen Maranatha, Vol. 1, No. 2 (diakses tanggal 18 Maret 2019).

Usman, Moh. Uzer. 2007. Menjadi Guru Profesional. Bandung: PT Remaja Rosdakarya. 